\title{
Scanning Electron Microscopic Study \\ on Corrosion Casts of Vascular \\ Structure of Rat Placenta
}

\author{
Jutaro Takahashi, Kaoru Sakuma, Mari SaIkudo \\ and Yasuhisa YASUDA \\ Laboratory of Animal Breeding, Faculty of Agriculture, Iwate \\ University, Morioka-shi 020
}

(Received March 14, 1984)

\begin{abstract}
The corrosion casts of maternal vasculature of rat placenta (from 15 to 19 days of pregnancy) were observed with the scanning electron microscope. Two spiral arteries coalesced to make a single trunk, then extended straight through the placenta toward the fetal side where it branched horizontally in fan fashion. These branches ramified into the dense and minute sinus. They repeated coalescing and ramification to build up labyrinth zone which were drained to the maternal vein. There were many protrusions on the minute vessels of labyrinth zone. Many depressions were observed on the surface of protrusions. These were suggested to be the replica of cytoplasmic protrusions of trophoblasts. Jpn. J. Zootech. Sci., 55 (10): 765-771, 1984
\end{abstract}

The rat has a hemotrichorial placenta with chorion that floats in the maternal blood sinus. Many histological studies of the vascular structure of rat placenta have been reported ${ }^{1-4)}$, but three dimensional features of vasculature have not been illustrated. Especially, there is no report illustrating corrosion casts of the blood sinus of the rat placenta with the scanning electron microscope (SEM). In the present experiment, modified resin injection corrosion casts of blood sinus of rat placenta were observed with SEM.

\section{Materials and Methods}

Female rats of the Wistar strain maintained in our laboratory and the Fischer 344 strain obtained from Japan Charles River Co. were used for present experiment. The day that the spermatozoa appeared in the vaginal smear was counted as day $O$ of pregnancy. After pregnant rats (from 15 to 19 days of pregnancy) were anesthetized by intramuscular administration of sodium pentobarbital ( $4 \mathrm{mg}$ per $100 \mathrm{~g}$ body weight), a V-shaped incision was made in the lower abdomen to expose the uterine horns. The arcuate artery and vein were perfused with $200-400 \mathrm{ml}$ heparinized saline solution by a 24 gauge needle attached to a $5 \mathrm{~m} l$ syringe into the descending aorta, giving pressure under $100 \mathrm{mmHg}$. The femoral veins, the femoral arteries and the ovarian arteries were ligated, and the ovarian vein and the vena cava caudalis were cut to exsanguinate the placental drainage. After complete perfusion with saline solution, methyl metharcylate resin (Mercox CL-2 B, Dainippon Ink Co. Ltd., 7-15 ml) 
was injected into placental blood vessels through the descending aorta. The resininjected placenta was placed in the incubator $\left(20^{\circ} \mathrm{C}\right)$ overnight and macerated by $10 \%$ $\mathrm{NaOH}$ solution $\left(36^{\circ} \mathrm{C}\right.$, for 3 days). And then, corrosion casts were washed by ultrasonic cleaner $(28 \mathrm{kHz}$, for $10 \mathrm{~min}$.). The specimens were coated with gold by an ion coater (Eiko Engineering Co. IB-3 type), and observed with SEM (Hitachi S450 ) at the acceleration voltage of $15 \mathrm{kV}$.

\section{Results}

Placental vascular casts made by injection of methyl methacrylate resin into the placenta through the maternal artery were investigated. The corrosion casts were observed with SEM from three dimensions, i.e. the fetal side, the maternal side and the vertical section. The macroscopical and microscopical structures of placental corrosion casts were observed.

\section{Structure of the fetal side}

On the center of the fetal side, dense and minute vascular structures and many large round holes $(120-250 \mu \mathrm{m})$ are present between the thick branches of the central artery (Fig. 1). There is a thick and ring-shaped vascular structure which surrounds the central branches and ramify to make the minute blood sinus forming outer part of casts. The dense and minute blood sinuses lead to the maternal side, showing ramification and coalescence (Fig. 2). Although the calibers of the minute blood sinuses are irregular, the calibers of the outside blood sinuses $(20-60 \mu \mathrm{m})$ seem to be thicker than those of inside $(10-40 \mu \mathrm{m})$. There are many protrusions on the minute blood sinuses (Fig. 2).

Structures of the maternal side

The dense and minute vascular structures coalesce to make thicker veins that lead to the maternal vein (Fig. 3).

\section{Surface of the vertical section}

The labyrinth zone is made up of dense and minute blood sinuses having many protrusions. Large holes in the center of the fetal side are demonstrated as a cylinder in the placental cast. Two spiral arteries $(260 \mu \mathrm{m})$ enter the placenta from the

\section{Explanation of Figures}

Fig. 1. Central feature of the fetal side of corrosion cast. Many large round holes (RH) are shown among the thicker branches (TB) of a central artery. The thicker branches lead to ring-shaped vessel which surrounds the thicker branches inside of the cast. (×26).

Fig. 2. Outer feature of the fetal side of corrosion cast. The structure consisted of the dense and minute sinuses is shown. The calibers of the outside sinuses are thicker than those of the inside $(\times 35)$. O: Outer side of sinus. I: Inner side of sinus.

Fig. 3. Feature of the maternal side of corrosion cast. The minute sinuses repeat coalescing to form the thicker veins (TV), and lead to the maternal vein $(\times 17)$. M: Maternal side. F: Fetal side.

Fig. 4. Feature of the vertical section of corrosion cast. Two spiral arteries (SA) coalesce into one artery, and stretches straight toward the fetal side. A part of ring-shaper vessel (RV) is shown. Many round hole-cylinders (RHC) are shown inside the cast ( $\times 20)$. CA: Central artery. TB: Thick branch. M: Maternal side. F: Fetal side. 
maternal side and fuse to make a single artery $(500 \mu \mathrm{m})$ that extends straight toward the fetal side where it branches (Fig. 4).

Surface of the casts of vessels

The central artery shows a smooth surface with large bud-like structures (Fig. 5). The protrusions of the minute blood sinuses of the inner labyrinth have many
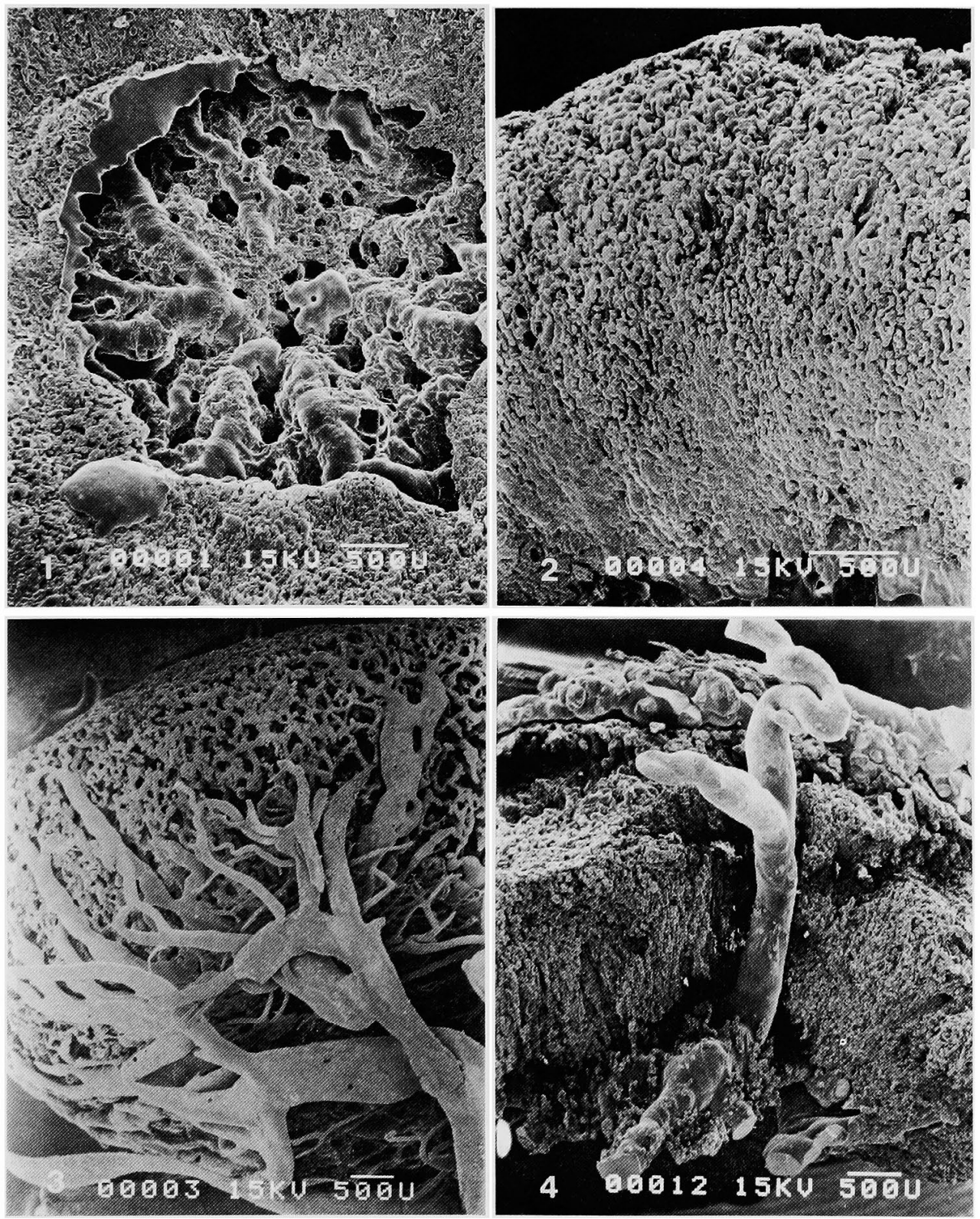
depressions (Fig. 6 and 7). The size of these depressions is $0.13-0.34 \mu \mathrm{m}$. On the other hand, the capillary structures of uterine vessels are different from the minute blood sinuses (Fig. 8).
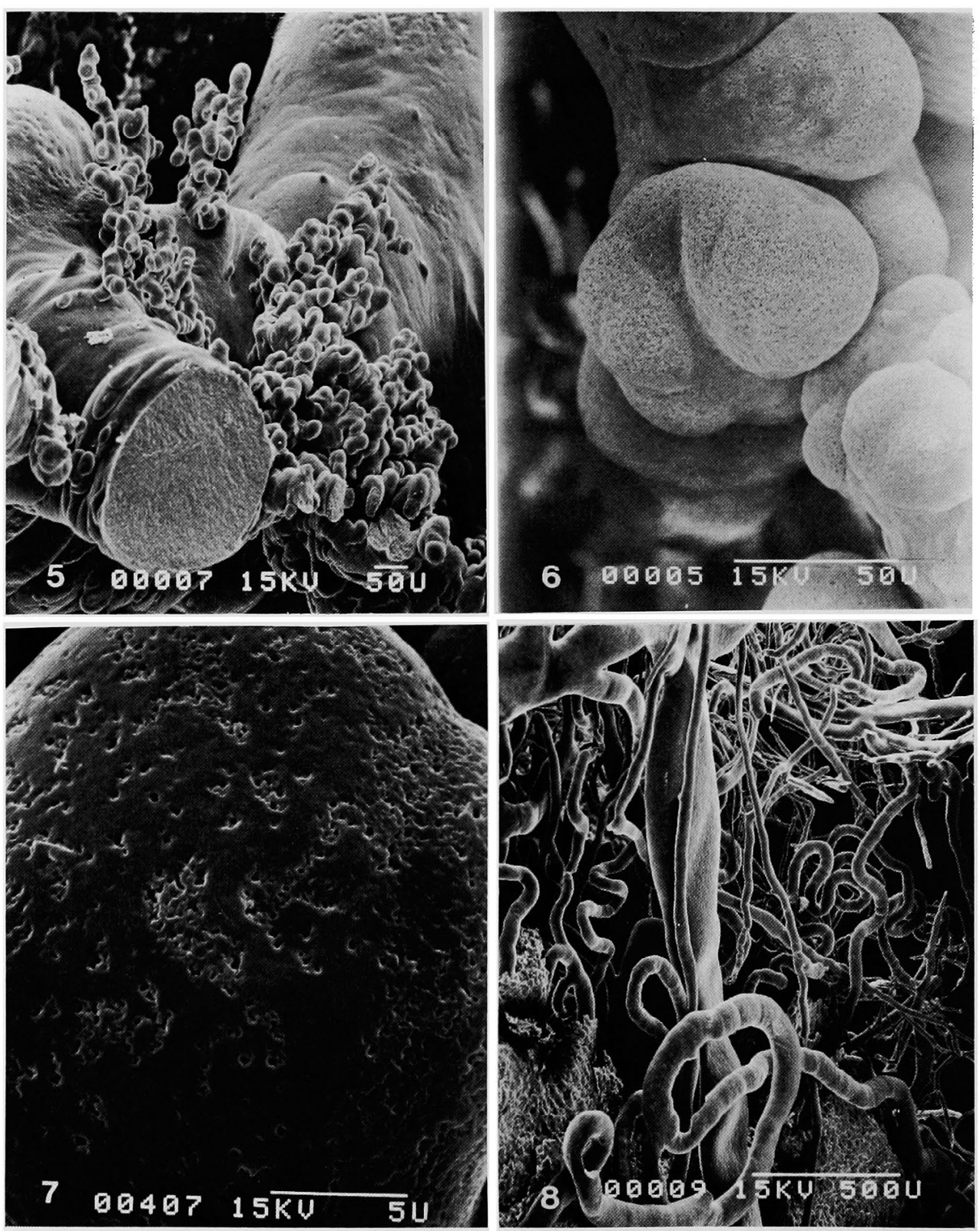

Fig. 5. Surface of the central artery (CA) of corrosion cast. Smooth surface with some budlike structures (BS) $(\times 120)$. TB: Thick branch.

Fig. 6. Surface of the protrusions (P) on the minute sinuses. Many depressions are shown on the surface. $(\times 640)$.

Fig. 7. Higher magnification of a protrusion. Many depressions (D) are shown on the surface. $(\times 5,000)$.

Fig. 8. Surface of the capillaries (C) of uterine vessels. $(\times 58)$. 


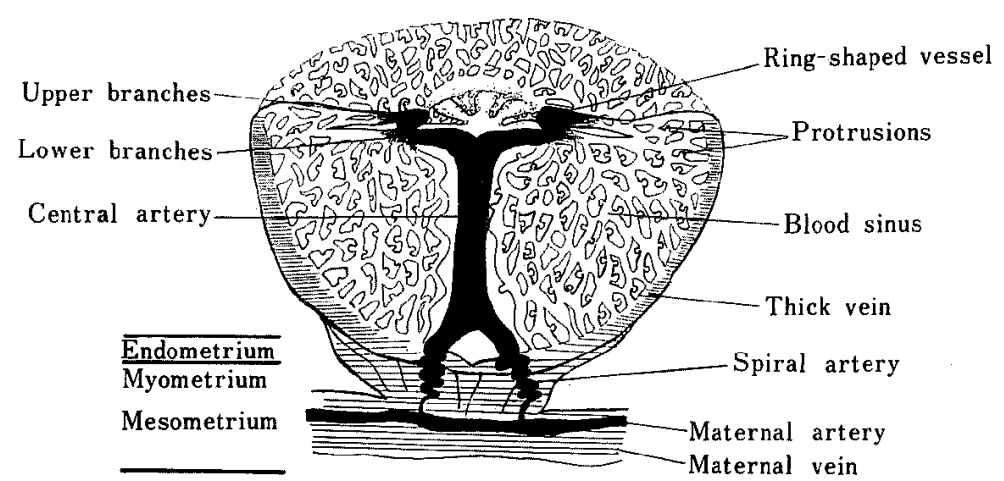

Fig. 9. Schematic diagram of vascular structure in rat placenta of late pregnancy

W: Artery Vein

\section{Discussion}

The schematic diagram of the rat placental vascular structure is illustrated in Fig. 9.

Two spiral arteries suddenly become thick just where they penetrate the basal zone of placenta, and coalesce into one trunk in the labyrinth zone. Then, the thick central artery stretches straight toward the fetal side where it branches horizontally. The upper branches form a thick ring-shaped vascular structure, while the lower branches ramify into the dense and minute blood sinuses. They repeat coalescing or ramification to form the labyrinth zone which leads to the maternal vein.

Except for an increment in volume, there was little difference with respect to the essential pattern of blood sinus among the rat placental casts (15-19 days of pregnancy).

Holmes and Davies ${ }^{7)}$ reported that two arteries were present in rat placenta of an earlier stage, but only one artery in late pregnancy (after 15 or 16 days). They described that it was not clear whether this was due to coalescence of the two arteries, or disppeaarance of one of them. Our study indicated that the two arteries coalesced into one artery after 15 days of pregnancy. The size of the labyrinth was observed to increase with the advance of pregnancy, especially the outer part rather than the central part.

$\left.\mathrm{B} \phi \mathrm{E}^{8}\right)$ investigated the fetal and maternal vasculature in the rat placenta with corrosion casts. Furthermore, LEE and DEMPSEY ${ }^{9)}$ studied the umbilical vasculature with corrosion casts with SEM, but they did not clarify the relationship between maternal and umbilical vasculature in the rat placenta. The several round large holes between the vascular branches in the central part and some gaps in the labyrinth zone are suggested to be the marks of the umbilical vessels. But the detailed feature of the relationship between maternal and fetal ciruculation remains unknown.

There are many protrusions on the minute blood sinuses. It is not clear whether they are traces of trophoblastic invasion into the blood sinus or processes to enlarge 
the area of maternal blood flow adjacent to the trophoblast. Although these protrusions must be investigated with transmission electron microscope, the latter possibility is more likely since they were observed more often in the region that gives more surface.

LEE and DEMPSEY ${ }^{9}$ reported that the surface of the umbilical artery showed imprints of nuclear impressions made by bulging nuclei of the endothelial cells in the observation of casts of rat placenta. In our experiment, however, the surface of the placental central artery was rather smooth without any nuclear impressions.

Holmes and DAvies ${ }^{7)}$ reported that the central artery is only a large blood channel through the placenta, with no real wall of their own. Therefore, the surface of the cast of maternal artery (central artery) seems to have no imprint of nuclear impressions.

METz et al. ${ }^{10)}$ reported that the feto-maternal blood barrier consists principally of five layers, i. e. the three trophoblastic layers (I, II and III), the perivascular space and the fetal capillary endothelium. The structure of the trophoblastic layer I (adjacent to maternal blood sinus) is characterized by cytoplasmic protrusions. Therefore, many depressions on the surface of casts are suggested to be the replica of cytoplasmic protrusions of the trophoblastic layer I.

\section{References}

1) Wislocki, G. B. and E. W. Dempsey, Anat. Rec., 123: 33-63. 1955.

2) Jollie, W.P., J. Ultrastruct. Res., 10: 27-47. 1964.

3) Enders, A. C., Am. J. Anat., 116: 29-68. 1965.

4) Dayies, J. and S. R. Glasser, Acta Anat. 69: 542-608. 1968.

5) Murakami, T., The Cell, 7: 11-18. 1975.

6) Kanzaki, H., H. Okamura, M. Mani, H. Morikawa, Y. Okuda, and T. Nishimura, acta obstet. Gynaec. Jpn., 32: 422-426. 1980.

7) Holmes, R. P. and D. V. Davies, J. Obstet. Gynec., 55: 583-607. 1948.

8) B $\phi E, F .$, Acta Endocrinol., 5: 369-375. 1950.

9) Lee, M. M. L. and E. W. Dempsey, Am. J. Obstet. Gynec., 126: 495-505. 1975.

10) Metz, J., D. Heinrich and W. G. Forssman, Anat. Embryol., 149: 123-148. 1976. 


\section{鋳型走査電子顕徵鏡法によるラット胎艋の 血管構築像の観察}

高橋寿太郎・佐久間 董 細工藤 真理・安田泰久

岩手大学農学部, 盛岡市 020

娃娠後期のラット胎盤にメチルメタクリレート樹脂を 母体血管より注入して，胎船血管の鋳型を作成し，走查 型電子影微鏡による観察を行なった.ラット胎船の血管 鋳型は妊娠 16 日以降で作成が 可能であり, 胎盤の母 体側血管の循環構造が三次元的に観察された. (1)子宮動 脈から 2 本の螺旋状動脈が胎盤に入り，胎盤の中でそれ らが 1 本に吻合し，太い血管を形成して胎児側の表面で 故射状に分岐した．(2)胎盤血管鋳型を縦に割断して観察
すると，中央の放射状に分岐した血管は胎盤内側と外側 に発達している徽細血管へ連絡し，迷路（Labyrinth）を 形成した. (3)胎船内側と外側の微細血管恃多数の突起を 形成し，分岐・痛合しながら緻密な網状構造を呈した。 さらに母体側に向い，より太い静脈を形成し，子宮静脈 一連絡していた。 (4)突起の表面には栄養膜細胞の細胞質 突起のレプリカと思われる多数の微細な小窩が認められ た. 日音会報, $55(10): 765-771,1984$ 